Volume $10 \quad$ Nomor 1, April 2020

Halaman $104-117$

\title{
REPRESENTASI PERNIKAHAN \\ DALAM MIDAH SIMANIS BERGIGI EMAS DAN GADIS PANTAI KARYA PRAMOEDYA ANANTA TOER
}

\author{
Stefani Ratu Lestariningtyas \\ Fakultas Ilmu Budaya, Universitas Padjadjaran \\ stefani13001@mail.unpad.ac.id \\ Muhamad Adji \\ Fakultas Ilmu Budaya, Universitas Padjadjaran \\ m.adji@.unpad.ac.id \\ Amaliatun Saleha \\ Fakultas Ilmu Budaya, Universitas Padjadjaran \\ amaliatun.saleha@unpad.ac.id
}

\begin{abstract}
Abstrak
Penelitian ini membahas dua karya Pramoedya Ananta Toer berjudul Midah Simanis Bergigi Emas (1955) serta Gadis Pantai (1962). Kedua karya ini menggunakan tokoh utama perempuan muda dengan mengangkat tema pernikahan dalam budaya patriarkis, serta mengungkit isu perjodohan, perceraian, serta kelas sosial yang meliputi tokoh perempuan di dalam kedua karya ini. Kedua karya ini menampilkan perjuangan Midah dan Gadis Pantai dari awal hingga akhir pernikahan mereka, serta pandangan mereka mengenai pernikahan yang telah mereka lalui. Penelitian ini menggunakan teori representasi untuk menganalisis unsur-unsur pernikahan di dalam kedua karya ini. Hasil dari penelitian ini menunjukkan kedua karya ini menampilkan permasalahan pernikahan yakni: (1) Permasalahan Kelas Sosial, (2) Pandangan Para Tokoh terhadap Pernikahan, dan (3) Representasi Perempuan Kuat. Hasil dari penelitian ini menunjukkan bahwa Pramoedya menampilkan masalah pernikahan melalui kehidupan Midah dan Gadis Pantai serta tokoh-tokoh yang ditemui Midah dan Gadis Pantai.
\end{abstract}

Kata Kunci: Pramoedya, Pernikahan, Kelas Sosial, Representasi

\begin{abstract}
This research examined Pramoedya Ananta Toer's works of Midah Simanis Bergigi Emas (1955) and Gadis Pantai (1962). Both of these works use young women as main characters with theme of marriage in patriarch culture, related to engagement, divorcement, and social class which are experienced by both female main characters. Both works shows struggles of Midah and Gadis Pantai from the beginning until the end of their marriage, as well as their views from their marriages. This research applies representation theory to analyze marriage aspects in both works. This research reveals that these two works show marriage problems: (1) Social Class Problem, (2) Characters' Views of Marriages, and (3) Representation of Strong Women. The results of this research shows that Pramoedya presents marriages problem from Midah and Gadis Pantai's life as well as other characters connected with them.
\end{abstract}

Keywords: Pramoedya, Marriages, Representation 


\section{PENDAHULUAN}

Sebagai bagian dari masyarakat, pengarang dapat menyajikan gagasannya melalui sebuah karya sastra. Karya sastra yang dapat dijadikan penyampaian pendapat berupa novel, syair, maupun cerita pendek. Selain untuk dibaca, karya sastra juga menyajikan informasi yang disajikan oleh pengarang dalam bentuk kisah fiksi (Welek \& Warren, 1993:4). Seperti halnya setiap sastrawan memiliki sifat tersendiri, maka sastrawan memiliki cara tersendiri untuk menyampaikan gagasan dalam bentuk karya sastra. Karya sastra dapat dijadikan sebagai representasi dari suatu kejadian, yang digunakan dalam karya sastra untuk menampilkan manusia beserta kebudayaannya secara tidak langsung (Ratna, 2010:14). Welek dan Warren menyetarakan karya sastra memiliki keunikan seperti manusia (Welek \& Warren, 1993:9). Para pengarang mengungkapkan pikirannya melalui karya sastra yang terinspirasi oleh kejadian yang terjadi pada masa mereka. Melalui karya sastra, mereka memasukkan gagasan terkait zaman mereka dalam karya sastra. Karya sastra menjadi sebuah media bagi pengarang untuk menunjukkan aspirasi mereka. Selain menjadi rekaman sejarah, karya sastra dijadikan sebagai wadah kritikan bagi anggota masyarakat maupun instansi masyarakat yang mereka singgung dalam karya mereka.

Penelitian ini membahas dua karya dari sastrawan ternama, Pramoedya Ananta Toer, yang berjudul Midah Simanis Bergigi Emas dan Gadis Pantai. Jakob Sumardjo menyebut novel Midah Si Manis Bergigi Emas merupakan saksi tertulis dari zamannya (Sumardjo, 1999:77). Savitri P Scherer (1981) menyebutkan hal serupa terhadap roman Gadis Pantai; roman Gadis Pantai merupakan rekaman sejarah sekaligus kritikan terhadap kondisi sosial pada awal abad 20 (Scherer, 1981:238). Novel Midah Simanis Bergigi Emas mengisahkan perjuangan seorang perempuan bernama Midah yang hidup di dalam budaya patriarki Betawi sehingga tidak berbuat banyak untuk melawan ketidakadilan yang ia terima dari lingkungannya sendiri. Namun dalam perjuangannya di masyarakat kelas sosial bawah, ia menerima penolakan karena dirinya melakukan pelarian dari keluarganya. Sedangkan roman Gadis Pantai mengisahkan perempuan di budaya Jawa yang mendapatkan status priyayi melalui pernikahannya dengan seorang Bendoro. Gadis Pantai yang berparas cantik dipinang oleh seorang Bendoro Rembang, Jepara. Namun karena perbedaan kelas sosial, Bendoro tidak datang untuk melamar serta menikahi Gadis Pantai. Bendoro mengirimkan seorang utusan untuk melamar orang tua Gadis Pantai, serta menggunakan keris sebagai perwakilan pada pernikahannya bersama Gadis Pantai. Bagi kaum priyayi, pernikahan tanpa kehadiran mempelai laki-laki merupakan hal yang biasa. Hal tersebut juga sudah diketahui oleh para pelayan Bendoro, yang sudah melayani para perempuan yang pernah diperistri dan diceraikan oleh Bendoro. Pernikahan tanpa kehadiran mempelai pria merupakan cara priyayi laki-laki untuk menunjukkan bahwa perempuan yang dinikahinya merupakan perempuan kelas bawah. Melalui pernikahan seperti itu, Gadis Pantai tidak diterima di kelompok priyayi dan masih dianggap sebagai perempuan dari kelas rendah.

Penelitian ini memusatkan perhatian pada pernikahan yang dialami Midah dan Gadis Pantai. Midah berasal dari habitus budaya Betawi pasca kemerdekaan, sedangkan Gadis Pantai berasal dari habitus budaya Jawa pra kemerdekaan. Meskipun mereka berasal dari habitus budaya dan masa yang berbeda, pernikahan Midah dan Gadis Pantai sama-sama melibatkan permasalahan kelas dan gender. 
Apabila Midah Si Manis Bergigi Emas mengisahkan seorang perempuan yang berasal dari lingkungan sosial atas yang memilih untuk keluar dari lingkungan sosialnya karena kegagalan pernikahan yang ia alami, Gadis Pantai mengisahkan seorang perempuan dari lingkungan sosial kelas bawah yang menjadi bagian dari masyarakat kelas atas karena pernikahan paksa. Persamaan dari Midah dan Gadis Pantai adalah mereka berjuang untuk mengatasi permasalahan pernikahan yang mereka alami. Di dalam kedua karya ini, tergambarkan beberapa masalah terkait pernikahan, meliputi perjodohan paksa, dan poligami serta pernikahan siri.

\section{METODE PENELITIAN}

Penelitian ini menggunakan karya Pramoedya Ananta Toer Midah Simanis Bergigi Emas dan Gadis Pantai. Kedua karya ini diterbitkan pada masa pasca kemerdekaan, dan karya sastra pasca kemerdekaan kecenderungan mengangkat isu kelas masyarakat (Sumardjo, 1999:29). Di dalam Midah Simanis Bergigi Emas dan Gadis Pantai pun, isu kelas sosial sangat kental diperlihatkan, termasuk kaitannya dengan masalah pernikahan. Selain isu kelas sosial, masalah pernikahan lain yang tampak dalam kedua karya ini ialah perjodohan, kekerasan dalam rumah tangga, serta perceraian. Permasalahan tersebut ditampilkan melalui perjalanan hidup serta tokoh utama, dan pandangan tokoh-tokoh lain terhadap kehidupan pernikahan tokoh utama. Penelitian ini mengkaji permasalahan terkait pernikahan menggunakan teori representasi yang digagas oleh Stuart Hall. Representasi adalah proses produksi makna dari sebuah konsep yang berasal pikiran melalui bahasa (Hall, 2003:3). Representasi merupakan cara untuk menampilkan konteks yang tersurat melalui teks. Pengarang menggunakan elemen-elemen sebagai alat bantu dalam menampilkan gagasan yang hendak mereka sampaikan. Elemen penting dalam analisis melalui representasi yang dimaksud seperti suara, kata, nada, gestur, ekspresi, baju, dan hal-hal lain yang penting dalam menampilkan gagasan pengarang (Hall, 2003:5). Teks menjadi media penyampaian gagasan yang harus dipahami secara tidak langsung, karena harus menganalisis elemen-elemen yang terkandung dalam teks untuk menganalisis gagasan pengarang yang disampaikan melalui karya sastra (Ratna, 2010:15).

Hall, dalam Hutashut, menjelaskan bahwa pendekatan yang digunakan dalam menganalisis representasi teks tidak hanya terkait bahasa dan representasi yang memberikan suatu makna, namun juga pemahaman yang mengkonstruksi identitas dan menjabarkannya sebagaimana apa yang direpresentasikan oleh elemen-elemen tersebut (Hutasuhut, 2016:3). Proses analisis representasi tidak hanya menampilkan masalah-masalah terkait elemen yang digunakan pengarang. Representasi mengaitkan elemen tersebut untuk menampilkan gagasan yang dimasukkan pengarang di dalam karya mereka. Elemen tersebut menjadi alat bantu bagi peneliti untuk menjabarkan wacana yang ditampilkan pengarang dalam karya sastra tersebut. Pendekatan representasi tidak menampilkan gagasan secara acak, namun gagasan yang sudah diklasifikasikan menjadi hubungan yang lebih rinci antar gagasan yang ditampilkan pengarang (Hall, 2003:4). Melalui analisis representasi, sebuah karya sastra tidak lagi menjadi sebuah karya fiksi belaka, namun menjadi suatu rangkaian gagasan dari masalah yang terkandung di dalam karya tersebut. Analisis representasi menguraikan unsur-unsur dari permasalahan dalam karya fiksi 
menjadi sebuah wacana yang lebih kompleks. Teknik analisis yang digunakan dalam penelitian ini ialah pendekatan deskriptif analitik yang mengurai unsur-unsur di dalam karya sastra untuk dianalisis (Ratna, 2010:88). Pendekatan ini merupakan pendekatan paling sesuai untuk teori representasi yang membongkar unsur-unsur dalam karya sastra yang digunakan pengarang untuk menampilkan masalah yang diangkat dalam karya mereka.

\section{HASIL DAN PEMBAHASAN}

\subsection{Masalah Pernikahan}

Midah dan Gadis Pantai merupakan putri sulung yang hidup di budaya patriarki, yakni budaya Betawi dan Jawa. Di dalam budaya patriarki yang mengenal kelas sosial, serta meletakkan peran pemegang kelas kepada laki-laki pernikahan merupakan salah satu cara untuk menaikkan maupun memertahankan kelas sosial bagi perempuan. Hal tersebut dialami oleh Midah dan Gadis Pantai. Midah yang berasal dari lingkungan masyarakat atas dijodohkan dengan seseorang yang berasal dari kelas sosial yang setara dengannya. Ketika Midah berusia 16 tahun, beberapa laki-laki mencoba untuk meminang Midah. Namun, semua lamaran tersebut ditujukan kepada Abdul, dan tidak ada satu lamaran pun yang mempertimbangkan keputusan Midah. Hingga suatu hari ibu Midah menyampaikan bahwa Abdul telah memilihkan calon suami untuk Midah. Melalui penuturan ibunya, Midah mengetahui seperti apa calon suaminya. Calon suami yang ditentukan ayahnya merupakan seorang laki-laki yang berasal dari kelas sosial atas, sama seperti Midah.

Kadang-kadang ia dengar ia dilamar. Kemudian setelah terbetik berita penolakan lamaran, ia tak dengar apa-apa tentang dirinya melalui pendapat orang lain. (...) Midah, sekarang engkau sudah besar. Sebentar lagi kawin. Jangan kira engkau tidak cantik. Sudah banyak bapakmu menerima lamaran. Tapi bapakmu hanya mau menerima lamaran kalau ada hadji dari Cibatok yang mengerjakannya. (...) Sekarang hadji yang diharapkan itu datang melamar pada bapakmu. Ia punya sawah banyak, kerbau berpuluh-puluh, ibadatnya kuat. Ah engkau akan mendapat suami yang baik, yang takut pada Tuhan. (Toer, 2009:20)

Lamaran yang Abdul terima namun tidak ia sampaikan kepada Midah menyebabkan Midah tidak diberi kesempatan untuk berpendapat terhadap lamaran yang semestinya ia ketahui. Midah sebagai perempuan tidak diberikan kesempatan untuk ikut berunding untuk memilih laki-laki yang akan menikahinya. Selain itu, Abdul hanya memilih laki-laki yang serupa dengan dirinya, yakni seorang hadji kaya yang berasal dari Cibatok. Kelas sosial Midah yang berasal dari lingkungan sosial atas dipertahankan dengan cara dinikahkan dengan seseorang yang sederajat dengannya. Di dalam budaya Betawi yang tidak mengenal kebangsawanan, latar belakang agama serta kekayaan sangat berpengaruh dalam menentukan kelas sosial seseorang. Dikarenakan Abdul sendiri seorang hadji kaya, maka Midah pun dinikahkan pula dengan seorang hadji kaya untuk memertahankan kelasnya. Abdul menikahkan Midah tidak hanya untuk memertahankan kelas sosial Midah, namun juga untuk menjaga prestis Abdul sebagai seorang terpandang di Jakarta. Melalui perjodohan yang ia tentukan kepada Midah, maka Abdul pun tetap dikenal sebagai seorang mertua dari seorang hadji Cibatok. Abdul menggunakan kekuasaannya sebagai kepala keluarga serta ayah bagi Midah dengan tidak mengizinkan Midah 
maupun istrinya untuk ikut memilih calon suami bagi Midah. Maka “(...) pada suatu hari yang mendung, Midah dikawinkan dengan Hadji Terbus dari Cibatok." (Toer, 2009:20). Midah segera dinikahkan dengan Terbus sehingga posisi Midah tidak lagi menjadi anak seorang hadji, namun menjadi istri seorang hadji. Kelas sosial Midah tetap sebagai masyarakat kelas atas melalui pernikahannya dengan seseorang yang setara dengan ayahnya.

Apabila Midah dinikahkan untuk memertahankan kelasnya, Gadis Pantai dinikahkan untuk menaikkan kelasnya, dari seorang warga kampung nelayan menjadi seorang priyayi. Keluarga Gadis Pantai yang berasal dari kampung nelayan menempati lingkungan sosial kelas bawah. Namun karena kecantikan Gadis Pantai, Gadis Pantai pun dilamar oleh Bendoro Rembang. Bendoro sebagai seorang laki-laki dari kelas sosial atas meminang Gadis Pantai melalui seorang utusan yang datang kepada orang tua Gadis Pantai, serta mewakilkan dirinya dengan sebuah keris di hari pernikahannya. Dikarenakan Bendoro sebagai seorang pejabat melamar Gadis Pantai, maka lamaran dan pernikahan yang dialami Gadis Pantai tidak lebih dari sebuah perintah yang diberikan Bendoro. Bendoro menunjukkan kekuasaannya atas Gadis Pantai dengan menggunakan keris sebagai wakilnya dalam pernikahan Gadis Pantai.
Maka pada suatu hari perutusan seseorang itu datang ke rumah orangtua gadis. Dan beberapa hari setelah itu sang gadis harus tinggalkan dapurnya, suasanya kampungnya, kampungnya sendiri dengan bau amis abadinya. (...) Kemarin malam ia telah dinikahkan. Dinikahkan dengan sebilah keris. Detik itu ia tahu: kini ia bukan anak bapaknya lagi. Ia bukan anak emaknya lagi. Kini ia istri sebilah keris, wakil seseorang yang tak pernah dilihatnya seumur hidup. (Toer, 2011:11-12)

Orang tua Gadis Pantai tidak menolak lamaran Bendoro meski lamaran tersebut tidak disampaikan oleh Bendoro sendiri. Sebagai warga kampung nelayan yang berada di lapisan masyarakat kelas bawah, orang tua Gadis Pantai tunduk pada perintah Bendoro yang meminta Gadis Pantai untuk dijadikan istrinya. Maka orang tua menasihati Gadis Pantai bahwa pernikahannya dengan Bendoro yang diwakilkan keris menjadikan Gadis Pantai sebagai bagian dari priyayi, sebagai istri seorang pembesar. Mereka menyebut bahwa Bendoro merupakan pilihan terbaik sebagai suami Gadis Pantai, karena Bendoro adalah seorang hadji dan bekerja sebagai bupati residen Rembang. Mereka pun mengiming-imingi Gadis Pantai mengenai kehidupan priyayi yang lebih ringan dibandingkan kehidupan sebagai warga kampung nelayan. Cara yang mereka lakukan untuk membujuk Gadis Pantai mengungkit mengenai kehidupan priyayi yang akan Gadis Pantai terima melalui pernikahannya dengan Bendoro.

"Sst. Jangan nangis. Mulai hari ini kau tinggal di gedung besar nak. Tidak lagi di gubuk, kau tak lagi buang air di pantai. Kau tak lagi menjahit layar dan jala, tapi sutera nak. Sst, sst. Jangan nangis. (...) Sst. Jangan nangis, nak. Hari ini kau jadi istri orang kaya." (Toer, 2011:12)

Melalui pernikahan, Gadis Pantai tidak lagi menjadi bagian dari masyarakat kampung nelayan, namun telah menjadi istri seorang priyayi. Bujang yang melayani 
Gadis Pantai pun menyebut bahwa Gadis Pantai merupakan "wanita utama" di rumah Bendoro tersebut, sehingga tugas Gadis Pantai adalah melayani Bendoro sebagai istri serta memerintah atas para pelayan di kediaman Bendoro. Meskipun telah menikah dengan Bendoro, Gadis Pantai mengalami alienasi kelas di rumah Bendoro maupun di kampung nelayan. Di kediaman Bendoro, Gadis Pantai dipanggil "Mas Nganten", sedangkan di kampung nelayan, Gadis Pantai sudah dipanggil "Bendoro Putri". Nama panggilan Gadis Pantai pun berubah-ubah, disesuaikan dengan tempat keberadaan Gadis Pantai. Di kediaman Bendoro, Gadis Pantai merupakan pelayan Bendoro, terutama dalam memenuhi kebutuhan seksual Bendoro. Gadis Pantai ditugaskan hanya untuk menyenangkan hati Bendoro, sehingga Gadis Pantai pun tunduk pada perintah Bendoro. Bendoro pun dengan tegas mengatakan kepada Gadis Pantai “(a)ku yang menentukan apa yang boleh dan tidak boleh, harus dan mesti kerjakan” (Toer, 2011:236). Di dalam pernikahan Gadis Pantai, Gadis Pantai tetap merupakan bawahan Bendoro, meskipun telah dinikahkan. Berbeda dengan di kampung nelayan, Gadis Pantai dikenal sebagai istri dari seorang pembesar. Gadis Pantai tidak lagi menjadi bagian dari warga kampung nelayan, melainkan istri pejabat. Para orang tua dan kenalan Gadis Pantai pun memanggil Gadis Pantai dengan sebutan "Bendoro Putri" untuk menghormati Gadis Pantai. Mereka pun melayani Gadis Pantai dengan menjamu Gadis Pantai selama dirinya mengunjungi kampung nelayan.

\subsection{Pandangan Para Tokoh Mengenai Pernikahan}

Orang-orang yang ditemui Midah dan Gadis Pantai setelah mereka menikah memiliki pandangan berbeda-beda terhadap pernikahan Midah dan Gadis Pantai. Sebagian besar dari mereka memiliki pandangan yang serupa, yakni perempuan yang sudah menikah merupakan milik suaminya. Selain itu, sebagian besar dari mereka juga berpendapat bahwa perempuan yang hidup di lapisan masyarakat kelas atas sebaiknya tetap berada di lingkungan tersebut dibandingkan ikut hidup menjadi bagian masyarakat kelas bawah. Pandangan mereka ini juga dipengaruhi oleh pengalaman, budaya patriarki, serta kelas sosial masing-masing tokoh. Pandangan para tokoh ini menuntut Midah dan Gadis Pantai untuk tetap bersama suaminya, terlepas dari ketidaknyamanan Midah dan Gadis Pantai yang hidup sebagai seorang istri dari laki-laki kelas sosial atas.

\subsubsection{Pandangan terhadap Keluarga}

Pandangan terhadap Keluarga yang dimaksud ialah pandangan terhadap keluarga Midah dan Gadis Pantai sebelum mereka menikah. Midah merupakan anak dari seorang hadji yang memiliki perusahaan kerajinan kulit. Midah pun hidup dengan berkecukupan karena ayahnya memiliki kekayaan yang menempatkan keluarganya di lapisan keluarga sosial atas. Untuk memertahankan kelasnya, Midah dijodohkan dengan seorang hadji kaya dari Cibatok. Namun kekerasan dalam rumah tangga yang dialami Midah, serta kenyataan bahwa ia dipoligami membuatnya melarikan diri. Tokoh pertama yang mengetahui pelarian Midah ialah Riah, bekas pembantunya. Riah menyarankan Midah untuk kembali kepada orang tuanya dibandingkan hidup menjadi perempuan kelas bawah. Riah yang pernah mengasuh Midah mengetahui bahwa Midah sudah terbiasa hidup sebagai perempuan kelas atas, bahkan dinikahkan dengan seorang yang setara dengan Midah. Midah menolak 
untuk kembali kepada orang tuanya karena takut akan ayahnya. Namun Riah memaksa Midah untuk kembali kepada orang tuanya, dengan menyampaikan bahwa kembali kepada orang tua Midah "(i)tu jalan yang paling gampang dan selamat." (Toer, 2009:24) dibandingkan melarikan diri dari suami tanpa tujuan.

Pandangan Riah bagi Midah untuk kembali kepada orang tuanya merupakan jalan paling aman bagi Midah sebab Riah mengetahui bahwa Midah terbiasa hidup sebagai perempuan kelas atas. Midah terbiasa dilayani serta hidup berkecukupan membuat Riah meyakini bahwa Midah tidak akan bisa hidup sebagai perempuan kelas bawah. Padahal Riah mengetahui bahwa Abdul memiliki perangai buruk, bahkan pernah memukul Midah ketika Midah masih berumur 9 tahun karena Midah memutar lagu keroncong di gramofon. Riah yang berasal dari lingkungan kelas bawah meyakini bahwa lebih baik Midah kembali kepada orang tuanya yag berada di lapisan kelas atas dibandingkan mencoba untuk bertahan di lapisan masyarakat kelas bawah. Riah tidak memertimbangkan kemauan Midah untuk mencoba hidup sebagai pengamen keroncong.

Tidak hanya Riah, Ahmad, seorang polisi yang ditemui Midah pun berujar hal yang serupa. Ahmad bertemu Midah ketika Midah mengamen sendirian setelah diusir dari grup pengamen keroncong setelah melahirkan anak pertamanya. Selain memertanyakan suami Midah, Ahmad juga menanyakan mengenai keluarga Midah. Ahmad juga menawarkan bantuan untuk mengantarkan Midah kembali kepada orang tuanya. Selain karena orang tua Midah memang sedang mencari Midah, Ahmad mengerjakan tugasnya sebagai polisi yang dimintai bantuan untuk menemukan Midah.

Riah dan Ahmad berpendapat bagi Midah untuk kembali kepada orang tuanya karena Midah berasal dari lingkungan kelas atas. Midah yang menjadi pengamen keroncong setelah meninggalkan suaminya dipandang sebagai pilihan yang lebih buruk dibandingkan kembali kepada orang tuanya. Pandangan ini berbanding terbalik dengan keluarga Gadis Pantai. Gadis Pantai berasal dari kampung nelayan yang dipersunting oleh Bendoro. Melalui pernikahannya, Gadis Pantai menjadi seorang istri pembesar.

Pernikahan tersebut memisahkan dirinya dengan orang tuanya karena perbedaan kelas. Bujang yang melayani Gadis Pantai pun menyebut bahwa orang tua Gadis Pantai, terutama ibu Gadis Pantai, telah menjadi "sahaya bagi mas Nganten" (Toer, 2011:58) dikarenakan Gadis Pantai telah menjadi seorang priyayi. Bujang tersebut mengatakan bahwa Gadis Pantai yang telah menjadi seorang wanita utama memiliki perbedaan kelas dengan orang tuanya. Maka orang tua Gadis Pantai pun harus melayani Gadis Pantai. Berbeda dengan Mardinah, yang ditugaskan menggantikan bujang tersebut, Mardinah memiliki pandangan lain. Mardinah berpendapat bahwa pernikahan Gadis Pantai dengan Bendoro tidak menjadikan Gadis Pantai bagian dari lingkungan kelas atas. Mardinah pun menghina orang tua Gadis Pantai yang "hanya seorang nelayan" (Toer, 2011:156) yang merujuk bahwa Gadis Pantai sebagai anak nelayan. Latar keluarga Gadis Pantai menjadi alat bagi Mardinah untuk menghina Gadis Pantai, sehingga Gadis Pantai tidak layak untuk berada di rumah Bendoro untuk waktu yang lama. 


\subsubsection{Pandangan terhadap suami}

Meskipun Midah memertahankan kelasnya melalui pernikahannya, Midah mengalami penindasan berupa kekerasan fisik dan psikis yang dilakukan Terbus. Ketika Midah melarikan diri dari suaminya, ia tidak kembali ke keluarganya. Midah enggan kembali kepada Abdul yang menikahkan dia dengan Terbus yang bersikap kasar serta telah melakukan poligami. Midah memilih untuk menjadi bagian dari masyarakat kelas bawah yang tidak memandang latar belakang seseorang seperti masyarakat kelas atas. Midah yang bersikeras untuk tidak kembali kepada orang tuanya pun memutuskan untuk bergabung menjadi pengamen di sebuah grup keroncong. Midah mengaku bahwa ia tidak memiliki keluarga kepada grup tersebut. Namun ketika Rois, ketua grup tersebut, mengetahui bahwa Midah mengandung dari seorang suami yang sah, ia pun meminta Midah untuk kembali kepada suaminya. Bahkan Rois menawarkan bantuan untuk mengantarkan Midah untuk kembali kepada suaminya. Rois berujar "(r)umah baik-baik adalah tempat yang paling aman buat wanita, bukan kehidupan rombongan pengamen seperti ini" (Toer, 2009:42). Rois menganggap Midah tidak layak untuk hidup sebagai bagian dari masyarakat kelas bawah, terutama pengamen keroncong yang tidak memiliki tempat tinggal tetap. Rois sebagai bagian dari masyarakat kelas bawah memandang masyarakat kelas atas merupakan lingkungan masyarakat yang baik-baik, karena lapisan masyarakat tersebut memiliki latar agama dan kekayaan yang baik. Midah yang tidak mau menceritakan asal keluarganya menyebabkan Rois pun tidak mengetahui alasan Midah meninggalkan suaminya. Rois memandang keluarga asal Midah sebagai keluarga yang baik terkait kelas sosial Betawi yang dapat dilihat melalui latar agama dan kekayaan. Rois tidak memertimbangkan kemungkinan bahwa Midah mengalami kekerasan fisik dan psikir yang membuatnya melarikan diri dari suaminya.

Tidak hanya Rois, Ahmad, seorang polisi yang ditemui Midah, juga memiliki pendapat mengenai keberadaan suami Midah. Midah bertemu kembali dengan Ahmad setelah Midah melahirkan anak pertamanya dan diusir oleh pengamen grup keroncong tersebut. Ahmad bertemu Midah yang bekerja sendirian untuk menghidupi anaknya sehingga menawarkan tempat tinggal di sebuah penginapan. Ketika Ahmad mengetahui bahwa Midah melarikan diri dari suaminya, Ahmad bertanya "(m)engapa dia tak kaukabari, atau engkau pergi ke tempatnya?" (Toer, 2009:85). Seperti Rois, Ahmad berpendapat bahwa Midah yang sudah menikah sebaiknya tetap tinggal bersama suaminya. Sebagai mantan anggota masyarakat kelas atas, Midah dianggap tidak layak untuk bekerja sendirian. Ahmad sendiri merupakan seorang polisi. Sebagai aparatur negara, Ahmad harus menjaga ketertiban masyarakat, termasuk untuk menertibkan perempuan-perempuan yang berkelana sendirian di kota Jakarta. Oleh karenanya, Ahmad memertanyakan alasan Midah tidak mengabari siapapun mengenai kelahiran anak pertamanya. Ahmad menganggap bahwa penting bagi seorang perempuan yang sudah menikah untuk hidup bersama suaminya.

Tokoh lain yang memiliki pandangan terhadap suami Midah ialah seorang bidan yang membantu kelahiran anak pertama Midah. Bidan tersebut memaksa Midah untuk menyebutkan nama suaminya. Midah bersikeras tidak menyebut nama suaminya sehingga bidan tersebut mengejek Midah "(j)adi harus anak empok dianggap anak haram?" (Toer, 2009:52). Bidan tersebut telah melayani banyak 
perempuan yang melahirkan, dan ia menjalankan tugasnya untuk mendata setiap kelahiran anak di rumah sakit tersebut. Namun ketika ia mendapati Midah yang tidak mau menyebut nama suaminya, bidan tersebut justru menyakiti Midah dengan menyebut bahwa anak Midah adalah anak haram. Keberadaan seorang suami menjadi penting bagi kelahiran seorang anak, namun hal tersebut membuat bidan tersebut menghina Midah dengan menyebut anak Midah sebagai anak haram.

Orang-orang sekitar Gadis Pantai juga memiliki pandangan yang baik terhadap suami Gadis Pantai. Gadis Pantai yang menikah dengan seorang Bendoro dianggap sebagai suatu kehormatan untuk Gadis Pantai. Orang tua Gadis Pantai juga memuji-muji Bendoro yang menikahi Gadis Pantai, meskipun menggunakan keris sebagai perwakilannya di hari pernikahannya. Pujian yang diujarkan orang tua Gadis Pantai merupakan cara bagi mereka untuk membujuk Gadis Pantai agar berhenti menangisi pernikahannya. Meski Gadis Pantai dinikahkan dengan sebuah keris, kelas sosial Gadis Pantai terangkat menjadi istri seorang bendoro melalui kacamata warga kampung nelayan.

“Beruntung kau menjadi istri orang alim, dua kali pernah naik haji, entah berapa kali khatam Qur'an. Perempuan nak, kalau sudah kawin jeleknya laki jeleknya kita, baiknya laki baiknya kita. Apa yang kurang baik pada dia?" (Toer, 2011:14)

Bagi orang tua Gadis Pantai, pernikahan Gadis Pantai merupakan suatu keberuntungan bagi Gadis Pantai. Gadis Pantai mendapatkan seorang suami yang, bagi orang tua Gadis Pantai, terbaik, dibandingkan para laki-laki dari kampung nelayan. Seperti Abdul yang memilih Terbus sebagai pasangan Midah dengan memerhatikan gelar hadji serta kekayaan Terbus, orang tua Gadis Pantai juga hanya memandang kebaikan Bendoro dari gelarnya sebagai Bendoro Rembang, kekayaan, serta ilmu agama yang dimiliki Bendoro. Orang tua Gadis Pantai memandang Bendoro sebagai sosok suami tidak bercela dari hal-hal yang dapat dilihat. Pandangan orang tua Gadis Pantai terhadap Bendoro berlainan dengan seorang bujang yang melayani Gadis Pantai. Bujang yang sudah bekerja pada Bendoro mengetahui bahwa Bendoro sudah menikah siri dengan beberapa perempuan sebelum Gadis Pantai. Bujang tersebut jugalah yang melayani serta mengajari empat perempuan yang pernah dinikahi Bendoro. Oleh karenanya, meski ia tunduk kepada Bendoro, bujang tersebut memahami bahwa Bendoro menggunakan kekuasaannya untuk berkali-kali menikah dengan perempuan dari kelas sosial bawah. "Ia tahu benar, dalam sehari wanita utama bisa berganti 25 kali tanpa sedikit pun mengurangi perbawa Bendoro." (Toer, 2011:98). Bujang tersebut juga berasal dari kelas sosial bawah. Maka, bujang tersebut menaruh hormat kepada Bendoro sama besarnya seperti kedua orang tua Gadis Pantai. Perbedaannya ialah bujang tersebut sudah mengenal Bendoro sebagai seorang pembesar yang dipuji banyak orang maupun sebagai suami dari istri-istri percobaan yang pernah bujang tersebut layani. Oleh karenanya, meskipun bujang tersebut memahami Bendoro yang menggunakan kekuasaannya untuk memiliki beberapa istri percobaan, bujang tersebut tetap menaruh hormat kepada Bendoro, dan tetap melayani Gadis Pantai. Bujang tersebut juga tidak menyebut sisi buruk dari Bendoro kepada Gadis Pantai sehingga mengajari Gadis Pantai hanya untuk melayani suaminya seumur hidupnya. Selama 
Gadis Pantai menjadi istri Bendoro, bujang yang melayani Gadis Pantai mengajari Gadis Pantai untuk bertingkah laku layaknya seorang wanita utama, alias istri seorang pembesar. Gadis Pantai tidak diperkenankan untuk melakukan pekerjaan kasar seperti yang biasa Gadis Pantai lakukan dulu. Namun yang lebih penting untuk dilakukan Gadis Pantai adalah melayani Bendoro. Gadis Pantai sebagai istri Bendoro harus tunduk serta melakukan apapun yang diperintahkan Bendoro dengan tujuan untuk menyenangkan hati Bendoro.

"Itulah salahnya, Mas Nganten, adat priyayi tinggi lain lagi. Dan ini kota, bukan kampung di tepi pantai." “Ah, lantas apa aku kerjakan di sini?" "Cuma dua, Mas nganten, tidak banyak: mengabdi pada Bendoro dan memerintah para sahaya dan semua orang yang ada di sini" (Toer, 2011:58)

Gadis Pantai yang pernah hidup sebagai warga kampung nelayan melihat pasangan suami istri di kampung nelayan saling membantu dalam kehidupan berumah tangga. Maka bujang tersebut menasihati Gadis Pantai, bahwa kehidupan pasangan di kota berbeda dengan di kampung. Sebagai seorang istri, Gadis Pantai tidak diizinkan untuk bekerja keras. Gadis Pantai harus menjaga kecantikannya untuk menyenangkan hati suaminya. Istilah "mengabdi" yang digunakan bujang tersebut berarti Gadis Pantai harus tunduk kepada segala keinginan suami. Bujang tersebut mendoktrin Gadis Pantai untuk hidup melayani suami seumur hidupnya. Secara tidak langsung, bujang tersebut menyebut bahwa Gadis Pantai pun merupakan bawahan Bendoro, meskipun statusnya adalah seorang istri. Namun bujang tersebut memilih untuk tidak menceritakan kenyataan bahwa suatu saat Gadis Pantai juga bisa diceraikan, seperti para istri percobaan sebelum Gadis Pantai.

Ketika peran bujang tersebut digantikan oleh seorang perempuan bernama Mardinah, Gadis Pantai mengetahui pandangan yang berbeda terhadap pernikahannya. Mardinah merupakan satu-satunya orang dari kelas sosial atas yang ia temui selama menjadi istri Bendoro, selain Bendoro sendiri. Sebagai bagian dari lingkungan priyayi, Mardinah mengetahui bahwa pernikahan priyayi yang sah merupakan pernikahan yang dilakukan oleh laki-laki dan perempuan priyayi. Apabila ada pernikahan lintas kelas, maka pernikahan tersebut merupakan pernikahan siri, yang menjadikan seorang perempuan sebagai selir, bukan sebagai istri. Mardinah bahkan menyebut bahwa "(b)endoro masih perjaka sebelum beristrikan wanita berbangsa"(Toer, 2011:155). Pernyataan yang dilontarkan Mardinah menandakan bahwa, dari kacamata priyayi, pernikahan Gadis Pantai tidak menjadikan Bendoro sebagai suami Gadis Pantai. Gadis Pantai bukanlah istri sah Bendoro, melainkan istri percobaan sebelum Bendoro menikah dengan seorang perempuan priyayi juga. Mardinah yang melayani Gadis Pantai berasal dari lingkungan priyayi. Meskipun ia mengakui dirinya sebagai pelayan Gadis Pantai, Mardinah memiliki harga diri lebih tinggi dari Gadis Pantai. Maka Mardinah pun tidak ragu untuk menyebut Bendoro sebagai perjaka karena Bendoro belum menikah secara resmi dengan perempuan yang setara dengannya. Mardinah pun mengatakan hal ini untuk mempermalukan Gadis Pantai yang, meskipun telah menikah dengan Bendoro, masih bagian dari masyarakat kelas bawah sehingga tidak dihitung sebagai istri seorang Bendoro. 
Gadis Pantai merasakan keterasingan setelah menjadi istri Bendoro. Oleh Bendoro dan Mardinah, Gadis Pantai masih dianggap sebagai masyarakat kelas bawah. Namun warga kampung nelayan menaruh hormat yang sangat besar kepada Gadis Pantai sehingga menyebut dirinya "Bendoro Putri". Bahkan para orang tua kampung nelayan yang lebih tua dari Gadis Pantai menaruh hormat kepada Gadis Pantai, hingga menegur anak-anak kampung nelayan yang masih memanggil Gadis Pantai dengan sebutan "Gadis Pantai". Kedatangan Gadis Pantai ke kampung nelayan setelah dinikahi Bendoro tidak lagi sebagai "Gadis Pantai" yang pernah menjadi warga kampung nelayan, namun seorang istri pejabat, sehingga warga kampung nelayan merasa terhormat dengan kedatangan Gadis Pantai. Bahkan orang tua Gadis Pantai merasa bahwa, meskipun mereka orang tua Gadis Pantai, posisi mereka membuat mereka tidak layak untuk berbicara kepada Gadis Pantai. Kelas Gadis Pantai yang sudah dinaikkan melalui pernikahan pun membuatnya terpisah dari orang tuanya bahkan kawan-kawan sepermainannya dulu. Namun di antara para warga kampung nelayan yang menyambut kedatangan Gadis Pantai, seorang laki-laki yang dipanggil Dul Gendeng tidak menerima kehadiran Gadis Pantai yang mengunjungi kampung nelayan. Dul Gendeng yang pernah tinggal di kota untuk belajar mengetahui mengenai kelas sosial yang ditetapkan di dalam budaya Jawa. Bagi Dul Gendeng, Gadis Pantai yang bukan bagian dari kelas sosial bawah tidak layak untuk berada di kampung nelayan. Dul Gendeng, melalui lantunannya, meminta Gadis Pantai untuk kembali ke kota untuk kembali bersenang-senang sebagai priyayi.

"Kembali kembalilah ke kota, emas berlian bawalah serta, di sana kesenangan menanti, di sini bukan tempat bendoro putri" (Toer, 2011:200)

Seperti orang tua Gadis Pantai, Dul Gendeng menganggap kehidupan Gadis Pantai setelah menikah dengan Bendoro merupakan sebuah keberuntungan karena tidak perlu bekerja keras seperti warga kampung nelayan. Bagi Dul Gendeng, kehidupan di kota serta kekayaan yang dimiliki Gadis Pantai sebagai istri Bendoro merupakan sebuah kesenangan yang menyebabkan Gadis Pantai tidak layak berada di kampung nelayan. Berbeda dengan warga kampung nelayan lainnya, Dul Gendeng menjadi pihak yang secara jujur menolak keberadaan Gadis Pantai di kampung nelayan karena Gadis Pantai status sosial Gadis Pantai yang telah dinaikkan melalui pernikahan. Apabila Mardinah yang berasal dari lingkungan priyayi menolak Gadis Pantai untuk menjadi bagian dari priyayi, Dul Gendeng menolak Gadis Pantai untuk kembali menjadi warga kampung nelayan.

\subsection{Representasi Perempuan Kuat}

\subsubsection{Pandangan Hidup}

Meskipun Midah dan Gadis Pantai hidup di budaya patriarki yang membuat mereka tidak dapat bersuara terhadap pernikahan mereka, Midah dan Gadis Pantai tetap menjalani kehidupan pernikahan mereka. Dalam kehidupan pernikahan mereka, mereka berjuang sebagai istri, meski pada akhirnya pernikahan mereka pun kandas. Selain itu, Midah dan Gadis Pantai pun menunjukkan peran sebagai seorang ibu yang mencintai anaknya, serta berjuang demi keselamatan anak mereka. 
Ketika Midah dijodohkan, ia tidak mengemukakan pendapatnya maupun melawan perjodohan yang ia terima dikarenakan trauma hebat yang ia terima dari ayahnya. Maka ketika Midah memutuskan untuk berpisah dari suaminya pun, ia memilih untuk tidak mengajukan gugatan cerai kepada suaminya, maupun meminta pendapat siapapun untuk menceraikan Terbus. Midah juga melakukan perlawanan terhadap pernikahan paksa yang dilakukan ayahnya dengan tidak kembali kepada orang tuanya. Midah yang meninggalkan suaminya dalam keadaan mengandung memantapkan hatinya untuk melakukan apa saja kecuali untuk kembali kepada suaminya maupun kepada orang tuanya. Sikap Midah yang meninggalkan suaminya dalam keadaan mengandung, serta datang ke rumah sakit sendirian untuk melahirkan anaknya juga menunjukkan Midah sebagai representasi perempuan kuat. Meskipun sikap tersebut membuatnya dicibir oleh beberapa orang termasuk dua bidan yang melayani Midah, Midah tetap tegar dalam menjalani kehidupannya sebagai masyarakat kelas bawah di budaya patriarkis Betawi.

Midah menjawab bahwa tidak sudi untuk kembali maupun menyebut siapa dan dimana suaminya kepada semua orang yang ia temui selama pelariannya, kecuali kepada Ahmad dan Riah yang ia percaya. Midah bahkan dengan tegas berkata "(a)ku tak sudi menyebut nama suamiku lagi" (Toer, 2009:52) kepada bidan yang menanyakan nama suaminya sebagai sebuah pernyataan bahwa ia membenci Terbus, laki-laki yang dipilihkan oleh orang tuanya. Meskipun Midah membenci Terbus, Midah mencintai anaknya yang berasal dari Terbus. Midah menaruh dendam kepada Terbus yang melakukan kekerasan terhadapnya, serta melakukan poligami tanpa sepengetahuan Midah. Namun kebenciannya terhadap Terbus tidak ia lampiaskan kepada anaknya, Rodjali. Midah berjuang menjadi pengamen pun didasari kecintaannya kepada Rodjali. Meskipun Rodjali adalah anak dari Terbus, namun Midah menampilkan sosok perempuan yang kuat sekaligus ibu yang penyayang selama menjalani kehidupannya sebagai seorang pengamen. Terlepas dari adaptasi yang dilakukan Midah sebagai bagian dari masyarakat kelas bawah Midah masih memegang moral yang dipelajarinya di keluarga Abdul. Meskipun ia tidak melawan perlakuan tidak menyenangkan dari beberapa laki-laki di Jakarta, ia berusaha menjaga dirinya dengan menolak tawaran maupun perlakuan para laki-laki tersebut. Bahkan Midah menegaskan "(w)alau aku hidup di jalanan, kak, aku bukanlah orang jalanan."(Toer, 2009:93) kepada Ahmad sebagai seorang polisi. Midah menegaskan bahwa ia tidak hidup sebagai perempuan jalanan, meskipun ia tidak memiliki tempat tinggal setelah diusir dari grup pengamen keroncong.

Pandangan hidup Midah berbeda dengan Gadis Pantai. Apabila warga kampung nelayan menganggap kehidupan Gadis Pantai sebagai istri Bendoro merupakan sebuah kesenangan, Gadis Pantai tidak merasakan hal demikian. Selama menjadi istri Bendoro, Gadis Pantai tidak dapat melakukan apapun sesuka hati. Setiap pekerjaannya diawasi oleh seorang bujang yang tunduk pada Bendoro. Bahkan, Bendoro yang merupakan suaminya memperlakukan Gadis Pantai sebagai bawahan. Meskipun Gadis Pantai mempelajari semua hal yang dianggap mampu menyenangkan Bendoro, Gadis Pantai tidak diperkenankan untuk mengenal Bendoro sebagai suaminya. Hal tersebut dikarenakan perbedaan kelas yang sejak pernikahan sudah ditegaskan melalui perwakilan keris. Selama pernikahan antara Gadis Pantai dan Bendoro masih terjalin, perbedaan kelas tersebut masih dipertahankan. Sebagai istri selir pun, Gadis Pantai tidak diperbolehkan untuk 
banyak berinteraksi dengan Bendoro, kecuali untuk hubungan seksual di kamar. Hal tersebut sudah disadari Gadis Pantai sejak tahun pertama pernikahannya bersama Bendoro.

Aku harus belajar segala, dari membatik, menyulam, sampai membaca dan mengaji. Terkecuali belajar tentang suami sendiri, bahkan juga pendapat suami tentang istrinya. (Toer, 2011:87)

Meskipun Gadis Pantai mengetahui bahwa dirinya merupakan bawahan Bendoro, Gadis Pantai memilih untuk mengikuti ajaran bujang yang mengajarinya. Gadis Pantai mengakui bahwa dirinya berada di rumah Bendoro untuk melayani Bendoro, "(s)ekarang ini kewajiban sahaya adalah mengabdikan diri pada Bendoro." (Toer, 2011:108). Selama menjadi istri Bendoro, Gadis Pantai tidak pernah menunjukkan perlawanan. Gadis Pantai melakukan tugasnya sesuai yang diajarkan bujang kepadanya. Bahkan ketika Mardinah menghina Gadis Pantai dengan menyebut Gadis Pantai “(c)uma sibuk di rumah seperti pesakitan,”(Toer, 2011:129) , Gadis Pantai tetap tidak terpengaruh dan memahami dirinya sebagai sahaya Bendoro. Gadis Pantai tidak merasakan banyak kesenangan sebagai istri Bendoro. Selain tidak dapat keluar rumah, serta harus menghabiskan banyak waktunya di kamar, perbedaan kelas antara Gadis Pantai dan Bendoro membuat Gadis Pantai terasing di rumah Bendoro. Bahkan keberadaan Mardinah membuat Gadis Pantai lebih tersiksa. Gadis Pantai tidak merasakan kesenangan seperti yang dianggap oleh warga kampung nelayan. Namun Gadis Pantai tetap memilih untuk mengikuti ajaran bujang yang pernah mengajarinya dengan tetap mengabdi kepada Bendoro.

Sayangnya sikap tunduk Gadis Pantai terhadap Bendoro tidak membuatnya bertahan sebagai istri setelah Gadis Pantai melahirkan seorang anak perempuan. Selama perjalanan ke rumahnya, Gadis Pantai merenungi kehidupannya selama menjadi priyayi. Setelah tiga tahun menjadi istri seorang priyayi, Gadis Pantai sudah belajar bermacam-macam untuk menjadi seorang wanita utama. Gadis Pantai pun sudah mempelajari kerendahannya sebagai seorang istri yang tidak diizinkan keluar rumah kecuali melalui izin Bendoro. Hal tersebut yang membuatnya membenci kehidupan lamanya sebagai priyayi. Gadis Pantai akhirnya menerima nasibnya untuk menjadi bekas selir Bendoro, serta harus meninggalkan bayinya di rumah Bendoro. Meskipun Gadis Pantai dan anaknya memiliki kelas sosial yang berbeda, Gadis Pantai mendoakan keselamatan putrinya yang menjadi bagian dari masyarakat priyayi sedari lahir. Gadis Pantai tidak mengharapkan dirinya akan menemui anaknya lagi.

\subsubsection{Peran sebagai Ibu}

Dalam budaya Jawa yang patriarkis, kehamilan seorang perempuan diharapkan akan melahirkan seorang anak laki-laki. Maka orang-orang di sekitar Gadis Pantai mengharapkan kelahiran seorang putra bagi Bendoro. Hal ini dipengaruhi budaya Jawa patriarkis sehingga keberadaan seorang anak laki-laki sangat diharapkan bagi sebuah keluarga. Ketika Gadis Pantai mengandung, seorang bujang yang mengetahui Gadis Pantai sedang mengandung pun mendoakan Gadis Pantai: “(s)emoga Tuhan mengaruniai Mas Nganten seorang putra." (Toer, 2011:246). 
Gadis Pantai diceraikan setelah ia melahirkan anak perempuan. Bendoro yang mengetahui bahwa anak yang dilahirkan Gadis Pantai adalah perempuan, Bendoro menunjukkan sikap ketidak sukaannya dengan berkata "(j)adi cuman perempuan?" (Toer, 2011:253) dan segera meninggalkan Gadis Pantai yang menggendong bayinya. Sikap Bendoro tersebut membuat Gadis Pantai sadar bahwa Bendoro kecewa karena tidak diberikan anak laki-laki, yang disebabkan oleh budaya Patriarkis Jawa yang mengharapkan kelahiran seorang anak laki-laki. Bahkan perceraian yang diterima Gadis Pantai pun tidak meminta pendapat dari Gadis Pantai sebagai istri. Bendoro memanggil ayah Gadis Pantai untuk menceraikan Gadis Pantai serta memberikan uang kerugian kepada ayah Gadis Pantai. Gadis Pantai yang terkejut mendengar bahwa ia diceraikan. Tugas Gadis Pantai selesai setelah Gadis Pantai melahirkan anak pertamanya, sebagaimana empat istri percobaan Bendoro lainnya terima.

Namun Gadis Pantai menolak untuk meninggalkan bayinya di rumah Bendoro, meski dia sudah tahu bahwa anaknya kelak akan menjadi seorang priyayi. Gadis Pantai merasa bahwa, sebagai ibu si bayi, ia memiliki hak untuk membawa bayinya pulang. Gadis Pantai memahami bahwa Bendoro mengharapkan kelahiran seorang anak laki-laki, serta merasa kecewa karena anak yang dilahirkan Gadis Pantai merupakan seorang anak perempuan. Maka Gadis Pantai tidak rela untuk membiarkan bayinya untuk diasuh oleh para sahaya Bendoro.

\begin{abstract}
“Sahaya ini emak si bayi. Kalau bapaknya pegang pun tak mau, apa pula merawatnya, Bendoro. Sebaiknya sahaya bawa pulang ke kampung. (...) Ayam pun bisa membela anaknya, Bendoro. Apalagi sahaya ini - seorang manusia, biar pun sahaya tidak pernah mengaji di surau." (Toer, 2011:263)
\end{abstract}

Pada akhirnya Gadis Pantai gagal membawa anaknya ke kampung nelayan. Setelah diusir secara paksa oleh pelayan Bendoro, Gadis Pantai pulang menggunakan sebuah dokar. Di dalam dokar tersebut ia mendoakan anaknya, "(d)ia anakku yang tak mengenal emaknya, tak kenal lagi air susu emaknya." (Toer, 2011:269) Meskipun ia terpisah dari anaknya, Gadis Pantai tetap mendoakan keselamatan anaknya. Selain itu, ia pasrah bahwa anaknya kelak tidak akan mengenalnya, dikarenakan perbedaan kelas antara Gadis Pantai serta anaknya. Meskipun Gadis Pantai membenci priyayi, namun ia tidak membenci anaknya yang merupakan anak Bendoro. Bahkan di akhir karya ini, Gadis Pantai tetap menjenguk rumah Bendoro demi melihat anaknya yang dirawat oleh para bujang Bendoro.

\title{
IV. PENUTUP
}

Kedua karya ini menampilkan banyak unsur mengenai permasalahan pernikahan. Permasalahan pernikahan di dalam kedua karya ini kental terkait masalah kelas sosial di budaya Betawi dan Jawa. Midah dan Gadis Pantai menikah untuk menjadi bagian dari masyarakat kelas atas. Di dalam pernikahannya, Midah dan Gadis Pantai mengalami perlakuan tidak menyenangkan dari suami. Perbedaannya ialah Midah memilih untuk meninggalkan suaminya, sedangkan Gadis Pantai tetap menjalani kehidupan pernikahnnya bersama Bendoro. Sikap mereka berdua pun terkait kelas, sebab Midah berasal dari masyarakat kelas atas, sedangkan Gadis Pantai berasal dari masyarakat kelas bawah yang menjadi seorang priyayi melalui pernikahan. Orang-orang yang mereka temui pun memiliki pendapat 
serupa. Sebagai perempuan yang sudah menikah, Midah dan Gadis Pantai harus tunduk kepada suami. Midah dan Gadis Pantai dituntut untuk tidak meninggalkan suaminya.

Permasalahan kelas menyertai kehidupan rumah tangga mereka. Midah yang meninggalkan suaminya pun diminta untuk kembali kepada suami maupun orang tuanya, karena Abdul dan Terbus berasal dari kelas sosial atas. Tokoh-tokoh yang Midah temui beranggapan bahwa hidup di keluarga masyarakat atas lebih baik bagi Midah. Demikian juga dialami oleh Gadis Pantai; beberapa tokoh seperti bujang dan warga kampung nelayan menyatakan bahwa kehidupan sebagai istri Bendoro yang tinggal di kota lebih menyenangkan dibandingkan tinggal di kampung nelayan. Hanya Mardinah dan Bendoro yang memandang Gadis Pantai tetap merupakan bagian dari masyarakat kelas atas. Perbedaannya ialah Bendoro tidak secara eksplisit menyatakan Gadis Pantai sebagai bawahan, sedangkan Mardinah mengungkit bahwa Gadis Pantai tetap menjadi masyarakat kelas bawah meskipun telah menikah dengan Bendoro.

Perceraian yang dialami Midah dan Gadis Pantai pun menunjukkan kekuatan mereka sebagai seorang perempuan termasuk seorang ibu. Midah dan Gadis Pantai mencintai anak mereka, meskipun laki-laki yang menjadi ayah dari anak mereka telah melukai mereka. Mereka pun memperjuangkan anak mereka, serta mendoakan keselamatan anak mereka. Perlakuan kasar yang mereka terima dari suami tidak membuat mereka membenci anak mereka. Meskipun perceraian membuat mereka menjadi masyarakat kelas bawah, namun pelajaran yang mereka ambil selama menjadi masyarakat kelas atas tetap mereka bawa hingga mereka kembali ke lapisan masyarakat kelas bawah.

\section{DAFTAR PUSTAKA}

Hall, S. (2003). The Work of Representation. In S. Hall (Ed.), Representation: Cultural Representations and Signyfying Practices. London: Sage Publication.

Hutasuhut, M. L. (2016). Language, Culture And Society: A Theoretical Analysis Of Stuart Hall's Representation And Signifying Practices.

Ratna, N. K. (2010). Sastra dan Cultural Studies: Representasi Fiksi dan Fakta (Vol. 3). Yogyakarta: Pustaka Pelajar.

Scherer, S. P. (1981). From culture to politics: the writings of Pramoedya A. Toer, 19501965.

Sumardjo, J. (1999). Konteks Sosial Novel Indonesia, 1920-1977. Bandung: Penerbit Alumni.

Toer, P. A. (2009). Midah, Simanis Bergigi Emas. Jakarta: Lentera Dirpantara.

Toer, P. A. (2011). Gadis Pantai. Jakarta: Lentera Dirpantara.

Welek, R., \& Warren, A. (1993). Teori Kesusastraan (Terjemahan melalui Budiyanto). Jakarta: Gramedia. 